\title{
BMJ Global Health Searching for accountability: can the WHO global action plan for refugees and migrants deliver?
}

\author{
Kristine Husøy Onarheim (D) ,1,2 Danielle Hanna Rached ${ }^{3}$
}

To cite: Onarheim KH, Rached DH. Searching for accountability: can the WHO global action plan for refugees and migrants deliver?BMJ Global Health 2020;5:e002095. doi:10.1136/ bmjgh-2019-002095

Handling editor Seye Abimbola

Received 18 0ctober 2019 Revised 20 April 2020 Accepted 22 April 2020
Check for updates

(c) Author(s) (or their employer(s)) 2020. Re-use permitted under CC BY-NC. No commercial re-use. See rights and permissions. Published by BMJ.

${ }^{1}$ Institute for Global Health, University College London, London, UK

${ }^{2}$ Department of Global Public Health and Primary Care, University of Bergen, Bergen, Norway

${ }^{3}$ Law School, Fundacao Getulio Vargas, Rio de Janeiro, Brazil

Correspondence to Dr. Kristine Husøy Onarheim; k.onarheim@ucl.ac.uk

\section{INTRODUCTION}

In the contemporary political moment, migrants and refugees are hypervisible. In 2018, there were 258 million international migrants, the majority residing in low-income and middle-income countries. ${ }^{1}$ While the global Sustainable Development Goals (SDGs) emphasise leaving no one behind and call for inclusion of migrants, ${ }^{2}$ few have examined how to meet this promise or the accountability mechanisms at play in migrants' health.

Mobility is not a new phenomenon, but large movements of people have provoked media and political disputes. ${ }^{3}$ For some, the management of migrants and non-citizens is framed as a security issue ${ }^{4}$ linked to the role of states and to national identity. ${ }^{5}$ For others, the emphasis is on migrants' contribution to the labour force and economic development ${ }^{6}$ or on human rights commitments. ${ }^{78}$ These narratives and framings differ greatly and illustrate how political forces clash in discussions on migration, health and governance. ${ }^{9}$

\section{GOVERNING THE HEALTH OF REFUGEES AND MIGRANTS}

Alongside heated debates on migration outside the health sector, there is increasing attention to the health of refugees and migrants. $^{7} 8$ 10-14 While many migrants are younger and relatively healthy (the healthy migrant effect), they face social, cultural and legal barriers that affect their health and access to care. ${ }^{14}$

Building on Frenk and Moon's analysis of major governance challenges for global health, we argue that migrant health is particularly prone to three persistent governance challenges; the sovereignty challenge, the sectoral challenge and the accountability challenge. ${ }^{15}$ The sovereignty challenge can be understood as the "inherent tension between the reality of national sovereignty and the

\section{Summary box}

While the literature on the health of refugees and migrants is growing, the governance challenges on migration and health remain neglected.

- Drawing on a conceptual framework on accountability, we assess whether the first WHO global action plan addressing refugees and migrants' health is equipped to fulfil its promise to promote their health and good migration governance.

- Looking beyond ethical and human rights-based ideas, the WHO global action plan relies on weak accountability mechanisms.

- Better global governance and accountability mechanisms are needed to promote action and accountability for refugees and migrants' health.

imperative of international collective action to properly manage interdependence'. ${ }^{15}$ In a world of sovereign states, there are few institutions and mechanisms in place to effectively protect migrants. Their health is left in the hands of national politicians, whose primary interests may not align with those faced by migrants. The sectoral challenge concerns how health is influenced by governance of non-health sectors. For example, whether and where a migrant has the opportunity to move, work or seek healthcare is often determined by policies made outside the health system. Restrictive regulations on immigration, welfare and citizenship may be harmful for migrant health. ${ }^{11}{ }^{14}$ The accountability challenge poses additional governance challenges. The global mechanisms to protect the human rights of migrants-including holding states accountable-are weak. ${ }^{16}$ Further, intergovernmental organisations may be accountable to their funders, their member states or a mix of these, and their interests may divert from those of refugees and migrants. The problem of accountability is also visible at the national level. Politicians are held to account by constituents, which may include long-term migrants, 
but rarely refugees, labour migrants and undocumented migrants. Decisions affecting migrants are therefore often made by stakeholders that do not answer to them. These challenges highlight why governance should be at the forefront of our current debates on migration and health. ${ }^{1718}$

\section{ACCOUNTABILITY ON MIGRATION AND HEALTH}

Several global mechanisms have been developed in light of the increased attention on migration and acknowledged need for international collaboration, including the Global Compact on Refugees, ${ }^{19}$ the Intergovernmental Conference to Adopt the Global Compact for Safe, Orderly and Regular Migration ${ }^{20}$ and the WHO global action plan: Promoting the health of refugees and migrants (the Plan). ${ }^{21}$ Further, the SDGs' emphasis on leaving no one behind puts attention to migrants. ${ }^{2}$ However, will these mechanisms be game changers for migrant health? In this commentary, we take a closer look at one of these mechanisms-the Plan-and assess whether its accountability mechanisms have the potential to fulfil its promise to 'assert health as an essential component of refugee assistance and good migration governance'.

As a complex political concept, accountability can be understood in different ways. ${ }^{2-26}$ By adopting a minimalist concept of accountability, a variety of interactions might occur between those who have the power to decide (power holders) and those who are affected by these decisions (account holders). ${ }^{23}$ Accountability only exists when power holders have the obligation to account and when account holders are entitled to demand an account for the actions or inactions of the power holders. In this sense, the Plan can be seen as an accountability mechanism. Here, the WHO is the major power holder, while member states, international agencies, refugees and migrants themselves, and others with an interest in refugee and migrant health are the account holders. One might rightly argue that the relationship between the WHO and its member states can be seen from a different angle. The WHO is governed by its 194 member states through the World Health Assembly. At the implementation phase of the Plan, member states could be seen as the ultimate power-holders and the WHO as an account holder. However, as the Plan is still in its earlier stages and is yet to be implemented, framing the WHO as the power holder seems more appropriate.

\section{ANALYSING THE WHO GLOBAL ACTION PLAN}

Drawing on Rached's conceptual framework on accountability, ${ }^{22}$ we analyse whether the Plan is duly equipped to do what it is meant to do; promoting the health of refugees and migrants. First, we describe the content of the Plan. ${ }^{21}$ As the Plan is yet to be implemented, we focus on its intentions rather than its effects. Second, we examine the Plan according to four functions of accountability; constitutional, democratic, epistemic and populist
Box 1 Four functions of accountability ${ }^{22}$

Accountability is examined through four normative functions.

Function I: Constitutional accountability (limits)

Function II: Democratic accountability (voice)

Function III: Epistemic accountability (informed decision-making

processes)

Function IV: Populist accountability (obedience)

(box 1). ${ }^{22}$ This framework has previously been applied to assess accountability arrangements in global health. ${ }^{27}$

\section{PROMOTING THE HEALTH OF REFUGEES AND MIGRANTS: A WHO GLOBAL ACTION PLAN (2019-2023)}

The first global action plan addressing the health of refugees and migrants was adopted by WHO member states in $2019^{21}$ following a decade of WHO-led consultations, resolutions and other activities. Given the normative and technical power of the WHO, its policies may promote sustained attention to an issue (agenda setting) and agreed-on action. Further, global action plans often set out expectations for different stakeholders and outline mechanisms to evaluate progress on the implementation. The scopes of various WHO global action plans range from refugees and migrants to antimicrobial resistance and mental health. Given the daunting governance and accountability challenges on migration and health, we argue that it is particularly important to examine this first Plan, its aspirations and mechanisms to achieve them.

The Plan sets the agenda for areas to give priority to (box 2) and outlines the actors involved in the implementation of the Plan. The scope is to 'assert health as an essential component of refugee assistance and good migration governance' (page 6).

\section{Box 2 Priorities of the WHO global action plan ${ }^{21}$}

1. Promote the health of refugees and migrants through short-term and long-term public health interventions.

2. Promote continuity and quality of essential healthcare, while developing, reinforcing and implementing occupational health and safety measures.

3. Advocate the mainstreaming of refugee and migrant health into global, regional and country agendas and the promotion of: refugeesensitive and migrant-sensitive health policies and legal and social protection; the health and well-being of refugee and migrant women, children and adolescents; gender equality and empowerment of refugee and migrant women and girls; and partnerships and intersectoral, intercountry and interagency coordination and collaboration mechanisms.

4. Enhance capacity to tackle the social determinants of health and to accelerate progress towards achieving the Sustainable Development Goals, including Universal Health Coverage.

5. Strengthen health monitoring and health information systems.

6. Support measures to improve evidence-based health communication and to counter misperceptions about refugee and migrant health. 
The Plan is intended to guide international organisations (including the WHO itself, the International Organisation for Migration (IOM), the United Nations High Commissioner for Refugees (UNHCR)), member states and non-state actors in promoting the health of refugees and migrants. It further outlines the specific responsibilities of the WHO and its secretariat as a director and coordinator on refugees and migrants' health.

Implementation of the Plan is contingent on national needs, contexts, priorities, legal frameworks and financial situation. It has no binding implications for individual member states. The Plan is a 'soft law' instrument intended to create norms, similar to other WHO strategies, action plans and guidelines. ${ }^{28}$ Soft law differs both in nature and functions from hard law, such as a WHO treaty to which member states have formal obligations to comply. On the one hand, soft law advantages includes informality, flexibility and normative influence on global agendas, national policies and laws. ${ }^{28}$ On the other hand, soft law opens up leeway for non-compliance, as there are no enforcement or financing arrangements.

\section{EXAMINING ACCOUNTABILITY MECHANISMS IN THE WHO GLOBAL ACTION PLAN}

What type of accountability arrangements does the Plan display? Are they appropriate to meet its intended goal to promote refugees and migrants' health? We examine the four normative functions that accountability arrangements are expected to play. ${ }^{22}$

\section{Constitutional accountability}

The objective of the constitutional function is to evaluate whether the Plan provides limits and checks on how power is exercised. According to the Plan, power is exercised by two actors: the WHO and member states. Although the Plan is a soft law instrument and member states will not be penalised if they fail to implement the Plan, it establishes mechanisms that might encourage member states towards implementing it, as well as to work closely with the WHO. First, the WHO secretariat is instructed to support member states on each of the six priorities (box 2). Second, member states are urged to report to the World Health Assembly on action taken. Third, the WHO director-general is requested to report to the World Health Assembly on the implementation of the Plan. Still, refugees, migrants and other actors (such as IOM, UNHCR and other international stakeholders) are not required to report on any action. While the Plan does not provide limits in the constitutional sense, it seeks to induce member states to comply with the Plan. In this way, it is intended to check on whether and how each country is implementing what they have committed to when adopting the Plan. Such 'inducement' can be understood as a 'soft' authority mechanism, but presupposes a fine comprehension of the behavioural determinants of the account holders.

\section{Democratic accountability}

The democratic dimension of accountability aims at giving voice or leverage to actors who might be influenced by the exercise of authority in a power relationship. The Plan can be seen as an instrument which expands the dialogue between involved actors and clearly sets out the roles of the WHO (coordinator and member of the United Nations Network on Migration), IOM and UNHCR (page 6). However, the democratic function of the Plan is hampered by its inability to reflect or include refugees and migrants in decision-making processes.

\section{Epistemic accountability}

The epistemic variant of accountability is concerned with the institution's ability to adopt better-informed decisions. This is possible if the power holder (the WHO) manages to develop mechanisms to gather and make use of information in decision-making processes. Priorities 5 (strengthening health monitoring and information systems) and 6 (improving evidence-based communication and countering misperceptions) describe intentions to promote more responsive and competent governance. These epistemic mechanisms can promote evidenceinformed decisions, and may address current inconsistencies and limitations of data on migration and health ${ }^{29}$ as well as dispel harmful myths. ${ }^{11}$

\section{Populist accountability}

The populist mechanism is attentive to the compliance and obedience from account holders. The Plan is the first shared global arrangement addressing the health of refugees and migrants. While its content and priorities cover important areas ${ }^{71} 29$ and legitimate actions are proposed, there are no financial resources or incentives for its implementation. The Plan does little more than to encourage compliance and obedience from the account holders. It relies heavily on ethical reasoning and human rights arguments, but it does not dwell on how political determinants and non-health policies affect refugees and migrants' health. ${ }^{79} 30$

\section{CONCLUSIONS}

Twelve years after the first WHO consultation on the health of migrants in 2008, the Plan represents the first shared global arrangement with an explicit focus on refugees and migrants' health. The Plan supports the normative idea that the health of refugees and migrants is important and sets expectations for the WHO, member states and the international community. It was developed alongside other global strategies and with inputs from partners, which may support its deliverability. ${ }^{2} 1920$ While encouraging, we argue that the accountability promise to 'assert health as an essential component of refugee assistance and good migration governance' has not been met. Except for the epistemic accountability, where the Plan aims at promoting evidenced-based approaches, the Plan falls short on the 
other normative promises (constitutional, democratic and populist).

Identifying and acknowledging these accountability gaps is the first step. The second step is to find ways to address them. The weak democratic and populist functions are particularly problematic. While WHO governance hinge on the WHO and member states as major stakeholders, the implementation and development of the Plan should include direct involvement of refugees and migrants. Such mechanisms are not unprecedented in international law (as demonstrated by the World Bank's Inspection Panel) or existing global health governance (seen in civil society representation on the board of the Global Fund). The WHO must lead by example and show that refugees and migrants must exercise central roles at the implementation phase of the Plan. For the populist function, the intentions to ensure obedience should be strengthened. While a shared global financing mechanism may not be politically feasible, independent international monitoring and review mechanisms could encourage compliance as well as issue attention. Actors such as academic institutions and civil society organisations may wield influence-through their expertise and moral and discursive power ${ }^{31}$-in promoting attention to voluntary reporting mechanisms by member states. Lastly, a cross-cutting principle should be to acknowledge and address the politicised narratives on migration that stand up against human rights and ethical arguments. ${ }^{9}$ While we recognise that WHO governance and diplomacy is political, it is crucial that the WHO Secretariat and regional bodies use its normative power and show leadership on promoting the health for all-including refugees and migrants.

While this analysis has highlighted some of the weaknesses of the Plan, we still hold that the normative expectations of the Plan, its priorities and guidance may be important in agenda-setting. Further, many of the limitations discussed here relate primarily to the shortcomings of soft law and global health governance generally. ${ }^{16}{ }^{18} 28$ At national level, countries have shown different degrees of inclusiveness in their approaches. In Thailand and Brazil everyone are entitled to healthcare services, including refugees and migrants. ${ }^{32} 33$ While these migrant-sensitive policies are promising, we question whether the good intentions of the Plan are enough to deliver on migration and health. We strongly support human rights and equity arguments to protect the health of migrants and refugees, but we worry that these imperatives stand up against competing interests, powers and political forces. ${ }^{34}$ The 73rd World Health Assembly in May 2020 represents an opportunity for the WHO and member states to acknowledge the strengths and weaknesses of the Plan and take action to promote better accountability mechanisms for refugees and migrants. Only then can we deliver on our promise to leave no one behind.
Twitter Kristine Husøy Onarheim @Krionarheim

Contributors $\mathrm{KHO}$ and DHR had the original idea. The first draft of the manuscript was prepared by $\mathrm{KHO}$, with critical input from DHR. The authors revised and approved the final version of the manuscript.

Funding The authors have not declared a specific grant for this research from any funding agency in the public, commercial or not-for-profit sectors.

Competing interests $\mathrm{KHO}$ volunteered as medical doctor in a healthcare centre for undocumented migrants in Bergen, Norway (2015-2017). DHR has no competing interests to declare.

Patient and public involvement Patients and/or the public were not involved in the design, or conduct, or reporting, or dissemination plans of this research.

Patient consent for publication Not required.

Provenance and peer review Not commissioned; externally peer reviewed.

Data availability statement All data are publicly available through the WHO website.

Open access This is an open access article distributed in accordance with the Creative Commons Attribution Non Commercial (CC BY-NC 4.0) license, which permits others to distribute, remix, adapt, build upon this work non-commercially, and license their derivative works on different terms, provided the original work is properly cited, appropriate credit is given, any changes made indicated, and the use is non-commercial. See: http://creativecommons.org/licenses/by-nc/4.0/.

ORCID iD

Kristine Husøy Onarheim http://orcid.org/0000-0001-8796-4782

\section{REFERENCES}

1 IOM UN Migration. Global migration indicators 2018.. International Organization for Migration, 2018.

2 United Nations. Transforming our world: the 2030 agenda for sustainable development. New York: United Nations, 2015.

3 A plan for Europe's refugees - How to manage the migrant crisis. The Economist 2016:06.02.16.

4 Weiner M. Security, stability, and international migration. Int Secur 1992;17:91-126.

5 Mednicoff D. Legal Regulation of Migrant Workers, Politics and Identity in Qatar and the United Arab Emirates. In: Kamrava M, Babar Z, eds. Migrant labor in the Persian Gulf. New York: Columbia University Press, 2012.

6 Betts A, Collier P. Refuge: transforming a broken refugee system. London: Penguin Random House, 2017.

7 Zimmerman C, Kiss L, Hossain M. Migration and health: a framework for 21st century policy-making. PLoS Med 2011;8:e1001034.

8 World Health Organization, United Nations High Commissioner for Human Rights, International Organization for Migration. International migration, health and human rights. Geneva, 2013.

9 Picard A. Louise Arbour: champion of international law. The Lancet 2018;392:2542.

10 Sweileh WM, Wickramage K, Pottie K, et al. Bibliometric analysis of global migration health research in peer-reviewed literature (20002016). BMC Public Health 2018;18:777.

11 Abubakar I, Aldridge RW, Devakumar D, et al. The UCL-Lancet Commission on migration and health: the health of a world on the move. Lancet 2018;392:2606-54.

12 Tulloch O, Machingura F, Melamed C. Health, migration and the 2030 agenda for sustainable development. Overseas Development Institute, 2016.

13 United Nations, Department of Economic and Social Affairs. International migration report 2015. New York. United Nations; 2016.

14 Castañeda H, Holmes SM, Madrigal DS, et al. Immigration as a social determinant of health. Annu Rev Public Health 2015;36:375-92.

15 Frenk J, Moon S. Governance challenges in global health. N Engl J Med 2013;368:936-42.

16 Ottersen OP, Dasgupta J, Blouin C, et al. The political origins of health inequity: prospects for change. The Lancet 2014;383:630-67.

17 Vearey J, Orcutt M, Gostin L, et al. Building alliances for the global governance of migration and health. BMJ 2019;366:14143.

18 Wickramage K, Annunziata G. Advancing health in migration governance, and migration in health governance. Lancet 2018;392:2528-30. 
19 United Nations. A73/12: Report of the United Nations High Commissioner for Refugees Part II. Global Compact on Refugees, 2018.

20 United Nations. Intergovernmental conference to adopt the global compact for safe, orderly and regular migration. In: Marrakech, Morocco, 10 and 11 December 2018. item 10 of the provisional agenda. Outcome of the Conference: United Nations, 2018.

21 World Health Organization. A72/25: Promoting the health of refugees and migrants. Draft global action plan, 2019-2023. Report by the Director-General, 2019. Available: https://www.who.int/publicationsdetail/promoting-the-health-of-refugees-and-migrants-draft-globalaction-plan-2019-2023

22 Rached DH. The Concept(s) of Accountability: Form in Search of Substance. Leiden Journal of International Law 2016;29:317-42.

23 Bovens M. Two concepts of accountability: accountability as a virtue and as a mechanism. West Eur Polit 2010;33:946-67.

24 Bovens M, Schillemans T, Hart PT. Does public accountability work? an assessment tool. Public Adm 2008;86:225-42.

25 Bovens M. Analysing and assessing accountability: a conceptual framework. Eur Law J 2007;13:447-68.

26 Mashaw JL. Accountability and institutional design: some thoughts on the grammar of governance. Camb Stud Law Soc2006:115.
27 Rached DH, Ventura DdeFL. World Health organization and the search for accountability: a critical analysis of the new framework of engagement with non-state actors. Cad Saude Publica 2017;33:e00100716.

28 Gostin LO, Sridhar D. Global health and the law. N Engl J Med 2014;370:1732-40.

29 Wickramage K, Vearey J, Zwi AB, et al. Migration and health: a global public health research priority. BMC Public Health 2018;18:987.

30 Juárez SP, Honkaniemi H, Dunlavy AC, et al. Effects of non-healthtargeted policies on migrant health: a systematic review and metaanalysis. Lancet Glob Health 2019;7:e420-35.

31 Moon S. Power in global governance: an expanded typology from global health. Global Health 2019;15:74.

32 Tangcharoensathien V, Thwin AA, Patcharanarumol W. Implementing health insurance for migrants, Thailand. Bull World Health Organ 2017;95:146-51.

33 Doocy S, Page KR, de la Hoz F, et al. Venezuelan migration and the border health crisis in Colombia and Brazil. Journal on Migration and Human Security 2019;7:79-91.

34 Miller S. Xenophobia toward refugees and other forced migrants. Waterloo, Canada: Centre for International Governance Innovation \& World Refugee Council, 2018. 